\title{
Weight Reduction in Young Obese Children. I. Effects on Adipose Tissue Cellularity and Metabolism
}

\author{
FREDDA GINSBERG-FELLNER ${ }^{(54)}$ AND JEROME L. KNITTLE \\ Department of Pediatrics, Mount Sinai School of Medicine of the City University of New York, \\ New York, New York, USA
}

\begin{abstract}
Summary
A 10-year longitudinal study was conducted on 26 prepubescent youngsters who had undergone successful weight reduction. Their ages ranged from 2 to 10 years when the study began. In all subjects, weight reduction proceeded only by a decrease in adipose cell size (from $0.62 \pm 0.02$ to $0.46 \pm 0.02 \mu \mathrm{g}$ lipid per cell) and resulted in a corresponding $33 \%$ decrease (from $177 \pm 6$ to 144 $\pm 5 \%$ ) in percent ideal body weights. Cell numbers did not change appreciably during the period of weight loss $(29.4 \pm 2.6$ versus 28.7 $\pm 2.3 \times 10^{9}$ total adipocytes). Three years after the start of the study, 14 of 20 youngsters had maintained their reduced percent ideal body weights, including eight who remained below $130 \%$ ideal body weight. Ten years later, only four remained below $130 \%$ ideal body weight. All four children had total adipose cell numbers below $20 \times 10^{9}$ total adipocytes at the start of the weight reduction program, a value below the lower limit for adult normal weight subjects. Thirteen other children have maintained or decreased their initial percent ideal weights. The remaining nine youngsters have further increased their percent ideal body weights. In vitro metabolic studies of the patient's adipocytes revealed a $>50 \%$ depression of epinephrine-stimulated lipolysis pre- and immediately postweight reduction; this decrease persisted for the entire period of study, irrespective of the maintenance of a normal percent ideal body weight. At the same time, normal $150 \%$ increases in the in vitro production of ${ }^{14} \mathrm{CO}_{2}$ from $\left[1-{ }^{14} \mathrm{C}\right.$ lglucose in the presence of insulin occurred.
\end{abstract}

\section{Speculation}

Maintaining weight reduction long term is generally unsuccessful except in a small minority of very young obese children. Therefore, if the prevalence of obesity and its associated diseases are to be decreased, very early identification of at-risk youngsters is important. Specific enzymatic and metabolic alterations in these children, e.g., depression of in vitro epinephrine-stimulated lipolysis, appear to be useful for early identification of susceptible individuals. In addition, this study indicates that factors such as genetics and gestation may lay the groundwork for the future development of increased adiposity.

Obesity, developing in childhood and persisting into adolescent and adult life, is associated with varying combinations of hypercellularity and enlargement of adipocytes $(1,20,29,45)$. However, weight loss is accomplished solely by a reduction in the size of the adipocytes; significant reductions in cell number have not yet been described. Weight loss, even if substantial, is almost invariably followed by some degree of weight gain to either previous or higher levels. Furthermore, a decrease in insulin insensitivity, a hallmark of the obese state, occurs in fat cells where the lipid content is reduced by dietary intervention. This is reflected by changes in glucose tolerance, serum insulin concentrations, and numbers and/or affinity of the cell membrane insulin receptors $(17,37,46)$. Adipocytes in obese adolescents also display diminished in vitro epinephrine responsivity pre- and immediately postweight reduction (28). Previous experiments in animals have shown that significant reductions in total adult adipose cell number can only be permanently achieved by altering early nutritional intake or by increasing early exercise patterns $(26,30,39)$. Thus, it is important to assess if a similar situation in young children exists to determine critical periods for fat cell development. The present investigation was designed to measure adipose cell number, size, in vitro responsiveness of adipocytes to insulin and epinephrine, plus the percent ideal weight in young obese children pre- and postweight reduction to assess the relative importance of these parameters on the ability to permanently maintain the reduced state.

\section{MATERIALS AND METHODS}

\section{SUBJECTS}

Twenty-six prepubescent children, 12 boys and 14 girls, ages 2 to 10 years at the start of the study, were investigated. They were originally referred to our Pediatric Nutrition Clinic because of obvious and significant obesity which was documented before their first birthday. All were tested and examined to exclude the concomitant presence of described endocrinopathies. They were then placed, as outpatients, on weight reduction diets calculated at approximately 50 calories $/ \mathrm{kg}$ of ideal body weight. Before the start of dietary intervention, adipose tissue studies, described below, were also performed. Five of 26 patients were studied only as outpatients; the remaining 21 were admitted to the Clinical Research Center (CRC) one to four times for periods ranging from 1 to $5 \frac{1 / 2}{2}$ months.

After admission to the CRC, all patients were placed on calculated food diets containing 40 to $45 \%$ carbohydrate. This enabled maintenance of their initial weight for periods ranging from 3 to 5 days. Baseline studies were performed after a 12-hr overnight fast, and all patients were then placed on a constant 400 calorie reduction diet. The diet (Table 1 ) was calculated to provide $21 \%$ of the total energy intake as protein, $45 \%$ as fat, and $34 \%$ as carbohydrate and was supplemented by $1 \mathrm{mg}$ folic acid daily, multivitamins twice daily, and $324 \mathrm{mg}$ ferrous gluconate every other day. In addition to two cans of diet soda, water was allowed ad libitum, and the amount was recorded. No other fluids were given. During the weight reduction period, daily strenuous physical activity was encouraged via the use of a gymnasium at the hospital and facilities at a neighborhood park and playground. Patients were weighed each day, urinalyses were performed daily, and serum uric acid and other blood determinations were made weekly. At the conclusion of the weight reduction period, each 
Table 1.400 calorie constant diet

\begin{tabular}{|c|c|c|c|c|c|c|}
\hline & $\begin{array}{l}\text { Volume } \\
(\mathrm{ml})\end{array}$ & $\begin{array}{c}\mathrm{Wt} \\
(\mathrm{gm})\end{array}$ & $\begin{array}{c}\text { Carbohydrate } \\
\text { (gm) }\end{array}$ & $\begin{array}{c}\text { Protein } \\
(\mathrm{gm})\end{array}$ & $\begin{array}{l}\text { Fat } \\
(\mathrm{gm})\end{array}$ & $\begin{array}{c}\text { Energy } \\
\text { (calories) }\end{array}$ \\
\hline \multicolumn{7}{|l|}{ Breakfast } \\
\hline Orange juice & 50 & & 5.2 & 0.4 & 0.1 & 22.5 \\
\hline Rice Krispies & & 10 & 8.8 & 0.6 & 0.0 & 39.0 \\
\hline Skim milk & 90 & & 4.6 & 3.2 & 0.1 & 32.4 \\
\hline Total & 140 & 10 & 18.6 & 4.2 & 0.2 & 93.9 \\
\hline \multicolumn{7}{|l|}{ Lunch } \\
\hline American cheese & & 22 & 0.4 & 5.1 & 6.6 & 81.4 \\
\hline Unsweetened peaches (drained) & & 50 & 4.1 & 0.2 & 0.1 & 15.0 \\
\hline Skim milk & 50 & & 2.5 & 1.8 & 0.1 & 18.0 \\
\hline Total & 50 & 72 & 7.0 & 7.1 & 6.8 & 114.4 \\
\hline \multicolumn{7}{|l|}{ Dinner } \\
\hline Ground sirloin patty (Raw wt.) & & 50 & & 8.5 & 13.4 & 156.5 \\
\hline Unsweetened applesauce & & 50 & 5.4 & 0.1 & 0.1 & 20.5 \\
\hline Skim milk & 50 & & 2.6 & 1.8 & 0.1 & 18.0 \\
\hline Total & 50 & 100 & 8.0 & 10.4 & 13.6 & 195.0 \\
\hline Additional: 2 cans diet soda & 720 & & 1.0 & & & 4.0 \\
\hline Grand total & 960 & 182 & 34.6 & 21.7 & 20.6 & 407.3 \\
\hline$\%$ total calories & & & 33.9 & 21.2 & 45.1 & \\
\hline
\end{tabular}

patient's weight was stabilized at the new lower level for 3 to 5 days on a diet calculated at approximately 50 calories $/ \mathrm{kg}$ of reduced body weight containing 40 to $45 \%$ carbohydrate. At the conclusion of this period, all the described baseline studies were repeated.

The patients were discharged and followed for periods ranging from 28 months to $9 \frac{1}{2}$ years. All the children were seen in the Pediatric Nutrition or Metabolism Clinics at 3- to 4-wk intervals by the same physician, a social worker, and a dietician from the CRC. No drugs, except for one multivitamin tablet daily, were administered. Recommended energy intakes ranged from 1000 to 1200 calories/day with each patient's diet being based on individual likes and dislikes for particular foods; protein intake was encouraged. Adipose tissue studies, as described below, were repeated at frequent intervals during the follow-up period.

The five outpatients were also seen at frequent intervals by the same physician, the clinic dietician, and social worker at each visit. Their diets ranged from 1200 to 1400 calories per day, and no drugs were used. Their studies were also performed pre- and postweight reduction after a 12 -hr overnight fast. Control data for metabolic studies were obtained from identical studies peformed on normal weight children with no family history of diabetes mellitus. Informed consent was obtained from both parents of all study participants.

\section{ADIPOSE TISSUE STUDIES}

Determination of adipose cell size and number. Adipose tissue samples of the patients were obtained from the subcutaneous tissue of the upper outer gluteal quadrant of the buttocks by needle aspiration; $1 \%$ xylocaine was used for local anesthesia (18, 19). The tissue fragments were immediately placed in KrebsRinger bicarbonate buffer and kept at $37^{\circ} \mathrm{C}$ under $95 \%$ oxygen and $5 \%$ carbon dioxide in a Thermos flask. The fragments were processed according to methods previously described (28). The lipid content per cell (adipose cell size) was measured in triplicate.

Total body adipose cell number was calculated from the follow- ing equation:

$$
\text { Cell number }=\frac{\text { body weight }- \text { lean body mass }}{\text { mean adipose cell size }}
$$

where the numerator is a measure of total body fat. Lean body mass was determined in all patients during the weight stabilization periods both from the Friis-Hansen nomograms (10) and from measurements of total body potassium (TBK) pre- and postweight reduction. The value for lean body mass is the mean of these two determinations.

TBK was measured in the whole-body counter located at Brookhaven National Laboratories, Upton, NY. The computer facility has an accuracy of $\pm 3.3 \%$ when measuring TBK. A complete description of the 54 detector Brookhaven counter has been published (5). Routine counting procedures involved a $15-\mathrm{min}$ count of the subject. Calibration of the counter was first performed. The whole-body count of the Alderson random phantom, containing a known amount of potassium homogeneously distributed, was obtained in the same geometry as that for the subjects. The count was corrected for geometry and absorption effects. For prepubescent children in this study, lean body mass in kilograms was determined by dividing total body potassium (milliequivalents obtained from the whole-body count) by $89 \mathrm{mEq}$ assuming that $1 \mathrm{~kg}$ of lean body mass contains $89 \mathrm{mEq}$ of potassium $(4,8,9,15)$.

Incubation of Tissue. Measurement of glycerol release. Individual fragments of adipose tissue were placed in $25 \mathrm{ml}$ siliconized Erlenmeyer flasks containing $2 \mathrm{ml}$ of Krebs-Ringer bicarbonate buffer ( $\mathrm{pH} 7.4)$ at $37^{\circ} \mathrm{C}$, glucose $(0.5 \mathrm{mg} / \mathrm{ml})$ and defatted fat-free albumin $(50 \mathrm{mg} / \mathrm{ml})$. Incubations were carried out as previously described (28). Glycerol was determined enzymatically by a modification of the Wieland method (51). Percent change, in the rate of glycerol release on the addition of $1 \mu \mathrm{g} / \mathrm{ml}$ epinephrine, was calculated from the following equation:

$$
\frac{(\text { epinephrine }- \text { basal) }}{\text { (basal) }} \times 100
$$


The rate of glycerol release was expressed as $\mu$ moles glycerol $\times$ $10^{-6} /$ cell $/ 4 \mathrm{hr}$.

Measurement of ${ }^{14} \mathrm{CO}_{2}$ production. Measurement of ${ }^{14} \mathrm{CO}_{2}$ production from $\left[1-{ }^{14} \mathrm{C}\right]$ glucose in the presence and absence of $100 \mu \mathrm{U} / \mathrm{ml}$ insulin was performed by methods previously described using individual fragments of adipose tissue (12).

Other measurements. Weight and height percentiles were obtained from Stuart and Meredith (48) and Center for Disease Control (14) growth charts for infants and children. Percent ideal weight was calculated as the ratio of actual weight to expected weight for height and age $\times 100$ on both charts; the mean of these two values is indicated. Statistical analyses were performed using the paired and unpaired $t$ tests; intercorrelation matrix analyses for cell size and cell number versus other parameters of body growth were performed (32).

\section{RESULTS}

Table 2 summarizes the data for each hospitalized patient at the first visit to the Nutrition Clinic and the beginning (period I) and end (period II) of the in-hospital weight reduction program. Means and standard errors of the means are shown at the bottom of each column. Similar data for the five children who lost significant weight as outpatients are shown in Table 3 . Fifteen of 21 hospitalized patients increased their percent ideal body weight $11 \pm 6 \%$ (from $169 \pm 8$ to $180 \pm 8 \%$ ) during the mean $10 \pm 3$ months which elapsed from the time they were first evaluated until the time of their first admission to the CRC. The remaining six of these 21 patients, however, decreased their percent ideal body weights $13 \pm 4 \%$ (from $171 \pm 7$ to $158 \pm 7 \%$ ) during a similar $16 \pm 6$ month time period. Although the group with such initial weight loss began its inpatient weight reduction program at a significantly lower percent ideal body weight (158 versus $180 \% ; P$ $<0.05$ ), the subsequent rate of weight loss and ultimate per cent ideal body weights were not altered by the initial outpatient weight loss. Thus, one patient in each of these CRC groups (M. C. and M. R.) ultimately remained below $130 \%$ ideal body weight. In each case, the weight loss which occurred (either outpatient or on the CRC) was achieved only by a decrease in cell size while cell number remained essentially unchanged. Mean cell number in the hospitalized patients was $29.4 \pm 2.6 \times 10^{9}$ total adipocytes on admission and $28.7 \pm 2.3 \times 10^{9}$ adipocytes on discharge. Identical decreases in cell size were seen in the six patients who underwent weight reduction more than once.

In the 21 hospitalized patients, average cell size decreased from $0.62 \pm 0.02$ to $0.46 \pm 0.02 \mu \mathrm{g}$ lipid per cell over a period of $8.2 \pm$ $0.7 \mathrm{wk}$, a decrement significant at $P<0.001$. Similarly, average cell size in the five outpatients decreased from $0.57 \pm 0.04$ to 0.46 $\pm 0.03 \mu \mathrm{g}$ lipid per cell. These facts are depicted graphically in Figures 1 and 2 for two patients who exhibited diametric longterm results after weight reduction. Data for patient $M$. C. are charted in Figure 1, in which arrows denote the time span of the in-hospital weight reduction program. His initial rapid reduction in weight when total adipocyte number was $15.3 \times 10^{9}$ cells resulted in a 4\% decrease in cell size over a period of 1 month although his percent ideal weight fell significantly from 150 to $110 \%$. Over the next 4 months, his percent ideal weight increased to $122 \%$. Over an approximately $71 / 2$-year interval, it has not risen above $130 \%$. Concomitantly, total adipose cell number increased slowly to a value of $20 \times 10^{9}$ adipocytes at age 10 . In contrast, patient I. G. (Fig. 2) was above $180 \%$ of ideal weight when she was first seen in the Nutrition Clinic at age 5 years and 7 months. Fifteen months later, she was admitted to the CRC, and over a 13 wk period, her percent ideal weight decreased from 202 to $172 \%$. Cell size decreased 10\%, and cell number remained unchanged at a mean value of $42.2 \times 10^{9}$ total adipocytes. After discharge, she rapidly gained weight and was then readmitted to the $C R C$ at age 9 years and 6 months. This time her percent ideal weight declined to $159 \%$ over a period of 3 months. Cell size decreased $30 \%$, whereas cell number remained unchanged at a mean $61.8 \times 10^{9}$ adipocytes. On discharge, she continued to gain weight and, postmenarche, is currently $290 \%$ of ideal weight. Her current cell number, $85 \times 10^{9}$, is $70 \%$ greater than the upper limit of normal for adults, $50 \times 10^{9}$ total adipocytes.

As indicated in Table 2, mean weight loss for all patients on the CRC was $8.9 \mathrm{~kg}$ over 8.2 wk or $1.1 \mathrm{~kg} /$ wk (range, 0.5 to $2.4 \mathrm{~kg} /$ wk with younger and lighter patients having the smaller weight loss and older and heavier ones having the larger weight loss). This occurred even though the daily energy intake ranged from 17.2 $\mathrm{kcal} / \mathrm{kg} /$ day in the lightest patient (M. C.) to as low as $4.3 \mathrm{kcal} /$ $\mathrm{kg} /$ day in the heaviest one (I. G.). Of this weight loss, $4.9 \mathrm{~kg}(55 \%)$ was calculated to be body fat loss. We then performed calculations to determine the validity of the two values used to derive total body fat. The correlation coefficient for the value, lean body mass, was the same for both the Friis-Hansen nomograms and TBK counts, namely 0.95 preweight reduction and decreased to 0.84 postweight reduction. As would be expected, the duration of weight loss correlated with the total fat and body weight loss $(P$ $<0.001)$. However, it correlated negatively $(P<0.01)$ with the present percent ideal weight, implying that children who underwent longer periods of weight reduction presently have greater percent ideal body weights. Before the in-hospital weight reduction, these 21 patients averaged $177 \pm 6 \%$ of ideal body weight. At the conclusion of the inpatient weight loss program, they had a mean ideal body weight of $144 \pm 5 \%$. Thus, they had lost $33 \pm 2 \%$ of their ideal weight, a loss significant at the $P<0.001$ level. At the first follow-up study, 6 months to 4 years after initial weight reduction had occurred, 15 re-evaluated patients had increased their percent ideal weights from $140 \pm 5 \%$ to $157 \pm 14 \%$, a value significant at the $P<0.05$ level. It is of interest, that four of these 15 patients were continuing to decrease their percent ideal weights, whereas nine showed increases, and two remained the same.

Furthermore, when these 15 patients were evaluated $4 \frac{1}{2}$ to $91 / 2$ years after initial weight reduction, their percent ideal weights had increased up to $183 \pm 11 \%$, a value significantly above $(P<0.05)$ the value 5 years previously. It exceeded, but not significantly, the value $181 \pm 8 \%$ which was calculated before any dietary intervention. From computations by intercorrelation matrix analyses (Table 4), individual total body weight, total body fat, weight loss, and fat loss in all patients correlated $(P$ at least $<0.05)$ with each other and with the age of the patient, total adipose cell number, and percent ideal body weight. This suggests that patients with the greatest body weights were older, had the largest amount of body fat, the highest total adipose cell numbers and per cent ideal body weights and lost the most weight and body fat during the weight reduction program. On the other hand, adipose cell size, unlike cell number, did not correlate with all the parameters cited above. Positive cell size correlations were consistently found only with total body weight at the beginning and end of the weight reduction period and with age on starting weight reduction. The $P$ values for the adipose cell size correlations were never as great as those for the cell number correlation. Thus, older children had larger fat cells and higher body weights. The percent ideal weight on the first visit to the Nutrition Clinic correlated $(P<0.05)$ with all subsequent percent ideal weights. It was noteworthy that girls came to the Nutrition Clinic at a lower percent ideal weight $(166 \%)$ than did boys $(177 \%)(P<0.01)$.

At the last follow-up, (mean $87 \pm 6$ months postreduction), the mean percent ideal body weight of all 26 patients, $177 \pm 9 \%$, was identical with their weight before dietary intervention, $177 \pm 5 \%$. At the initial follow-up, eight hospitalized children and three children treated as outpatients were below $130 \%$ ideal body weight. Five years later only four remained at this percentage while two others were between 130 and $140 \%$ ideal weight. The four youngsters had initial total adipose cell numbers of $13.2,13.4,15.3$, and $19.4 \times 10^{9}$ whereas the latter two had values of 18.4 and $27.4 \times$ $10^{9}$. These data demonstrate that the two children hospitalized for weight reduction and two who had lost weight as outpatients maintained their lower, relatively normal weights for several years. Moreover, maintenance of nearly normal percent ideal body 
Table 2. Studies in hospitalized obese children pre-and postweight reduction: admission to CRC

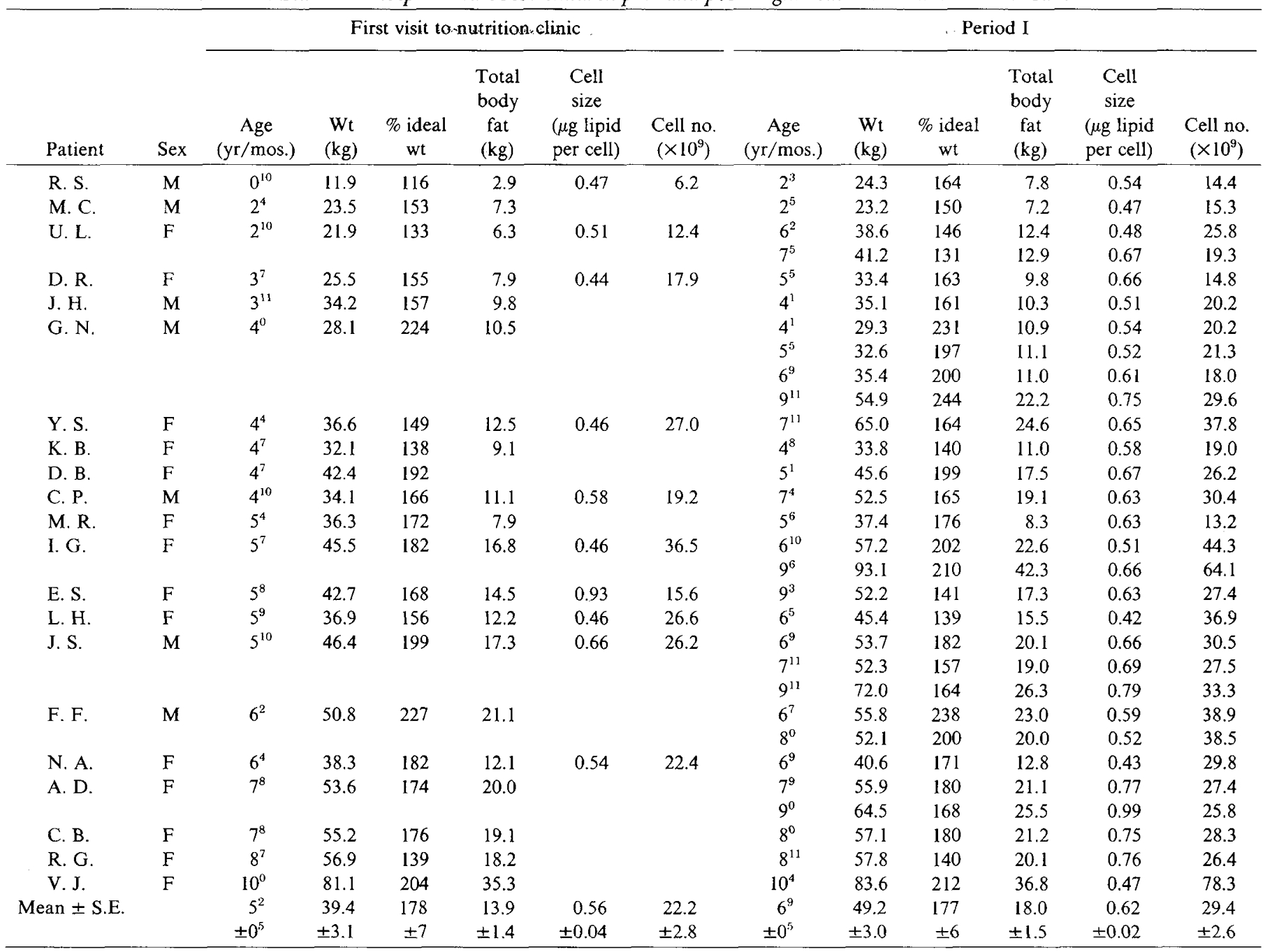

Table 3. Adipose tissue studies pre-and postweight reduction in ambulatory obese children

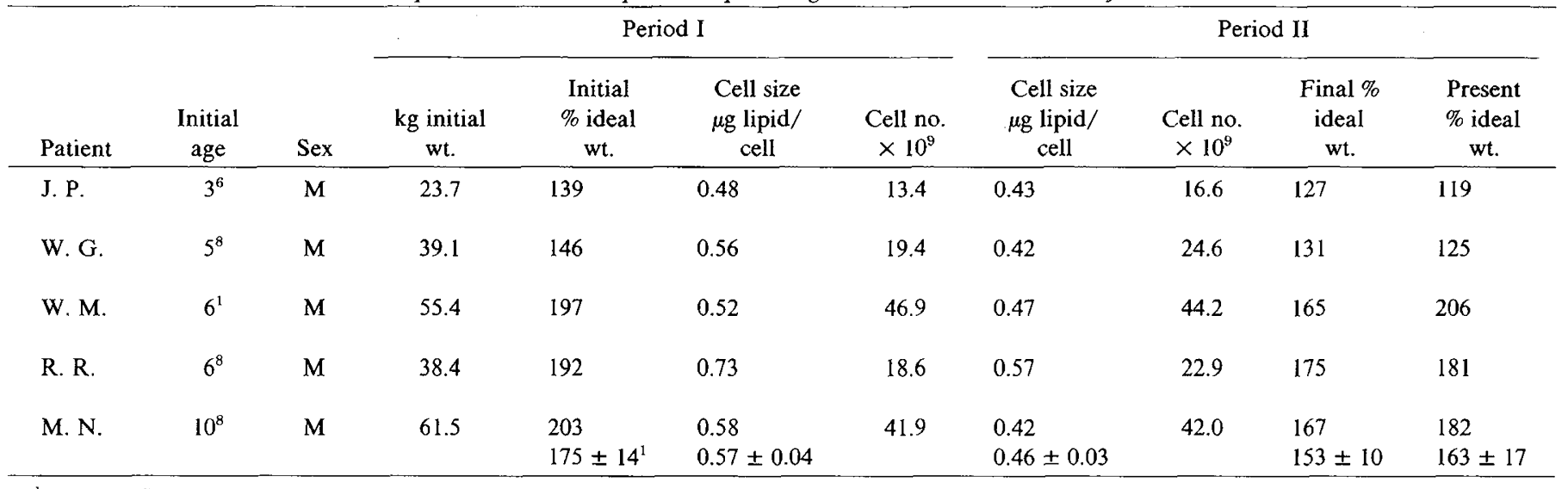

\footnotetext{
${ }^{1}$ Mean \pm S.E.
}

weight was not dependent on the weight at the time of completion of the weight reduction program. Six patients who were reduced to below $130 \%$ ideal weight later again became obese.

Figure 3 and Table 5 summarize the data on in vitro responsiveness of aspirated adipocytes to epinephrine $(1 \mu \mathrm{g} / \mathrm{ml})$ which was measured by glycerol release during a $4 \mathrm{hr}$ incubation period. Our previously reported data on obese adolescents and adults are included for comparison (28). The mean age of 14 control children, $6.6 \pm 0.7$ years, was similar to that of our obese children. The mean in vitro responsiveness averaged $127 \pm 21 \%$ over baseline values for controls whereas the mean for obese children before weight reduction was only $49 \pm 9 \%(P<0.05)$. Furthermore, this defect was not corrected by weight reduction, even in the youngest patients. Immediately postweight reduction, epinephrine-stimu- 


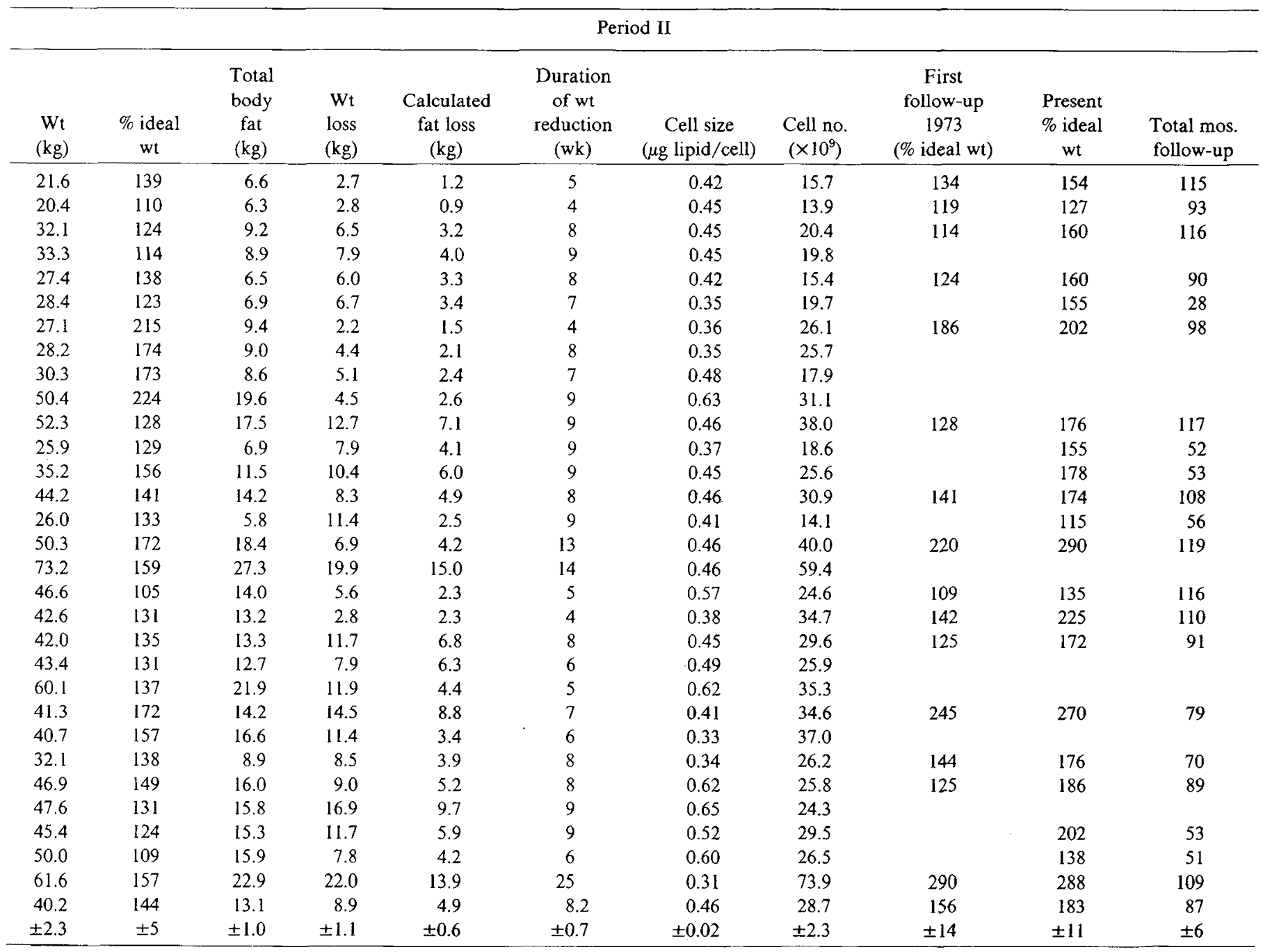

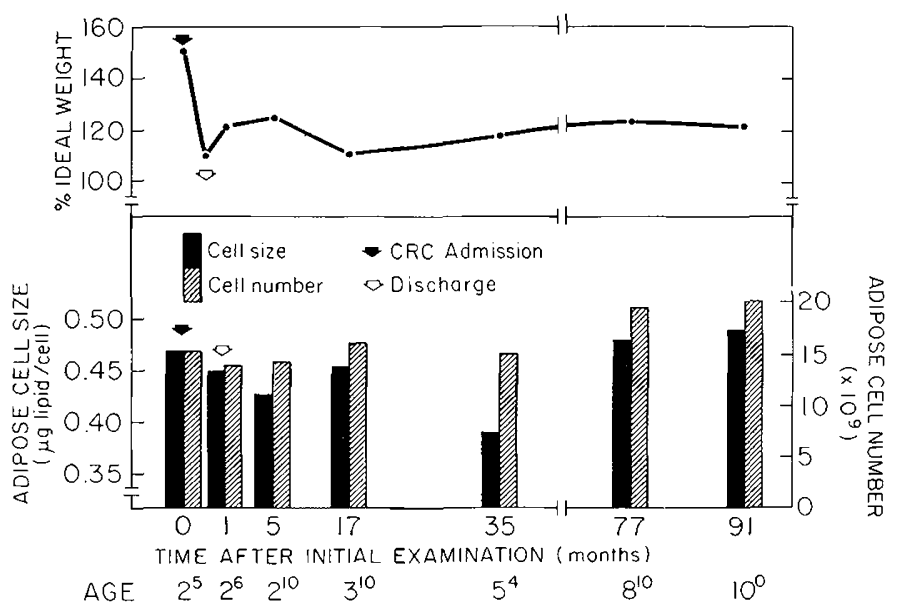

Fig. 1. Percent ideal body weight, adipose tissue cell size, and cell number over 93 months time span in patient $M$. C.

lated lipolysis decreased slightly, to a mean value of $40 \pm 13 \%$. It was maintained $19.4 \pm 8.2$ months later at an average of $52 \pm 7 \%$ and at $6.4 \pm 2.4$ years the mean was $45 \pm 6 \%$. Epinephrinestimulated lipolysis did not return to normal in any of the patients irrespective of their age or maintenance of ideal body weight below $130 \%$. Mean basal glycerol release declined $22 \%$ after weight reduction as mean cell size decreased $25 \%$. This confirms the fact that basal glycerol release correlates with cell size $(\mathrm{r}=0.78 ; P<$ 0.0002 ). Basal glycerol release was increased during both study periods in the obese children; however, its postreduction release was only minimally above the control childrens' value at the same time when mean fat cell sizes in the obese were identical to those in the controls. Both the percent increase in lipolysis and the absolute glycerol release in the presence of epinephrine were consistently decreased in the obese patients during all study periods. Absolute levels of epinephrine-stimulated lipolysis did not correlate with cell size in either study period but as cell size decreased with weight reduction these levels also fell.

"Normal" in vitro responses of adipocytes from obese subjects to $100 \mu \mathrm{U} / \mathrm{ml}$ of insulin were measured by conversion of $\left[1-{ }^{14} \mathrm{C}\right]-$ glucose to labeled carbon dioxide (Fig. 4). Conversion occurred even though the cell size of these obese patients decreased significantly to $0.48 \pm 0.02 \mu \mathrm{g}$ lipid per cell after weight loss $(P<0.001)$. These values of the obese patients during both study periods were also similar to those of the control patients whose cell size averaged $0.48 \pm 0.04 \mu \mathrm{g}$ lipid per cell in this study.

\section{DISCUSSION}

The onset of obesity in children described in this paper occurred before their first birthday. They displayed hyperplastic fat depots when compared with normal children of the same age and height 
(27). The significance of adipose tissue hyperplasia and the techniques for calculating the total number of fat cells in a given individual have been the subject of intensive debate. Nonetheless, our previous cross-sectional and longitudinal studies of adipose cell development and body composition in children and adolescents have confirmed that obese children can be identified by fat cell characteristics as early as age two, if not earlier $(29,32)$. These studies demonstrate conclusively that obese children, when followed longitudinally, continue to exhibit adipose tissue hypercellularity. Although the buttock area has been used for adipose tissue sampling in these studies, it has been shown that correlations exist between fat cell sizes of different regions of the body. It may be inferred that samples obtained at a single site from a large group of subjects can provide a reasonable estimate of the variation among individuals in fat cell sizes in all depots (7). Fat cells isolated by needle aspiration from the buttocks have been shown by Khan et al. (25) to be about $7 \%$ smaller than those from the abdomen. Errors in calculating total body fat cell number may then occur, but such differences only change absolute values, not trends. Thus, although the number of adipocytes calculated cannot be determined exactly, ranges for different degrees of obesity can be extrapolated. Furthermore, in such longitudinal studies, it is

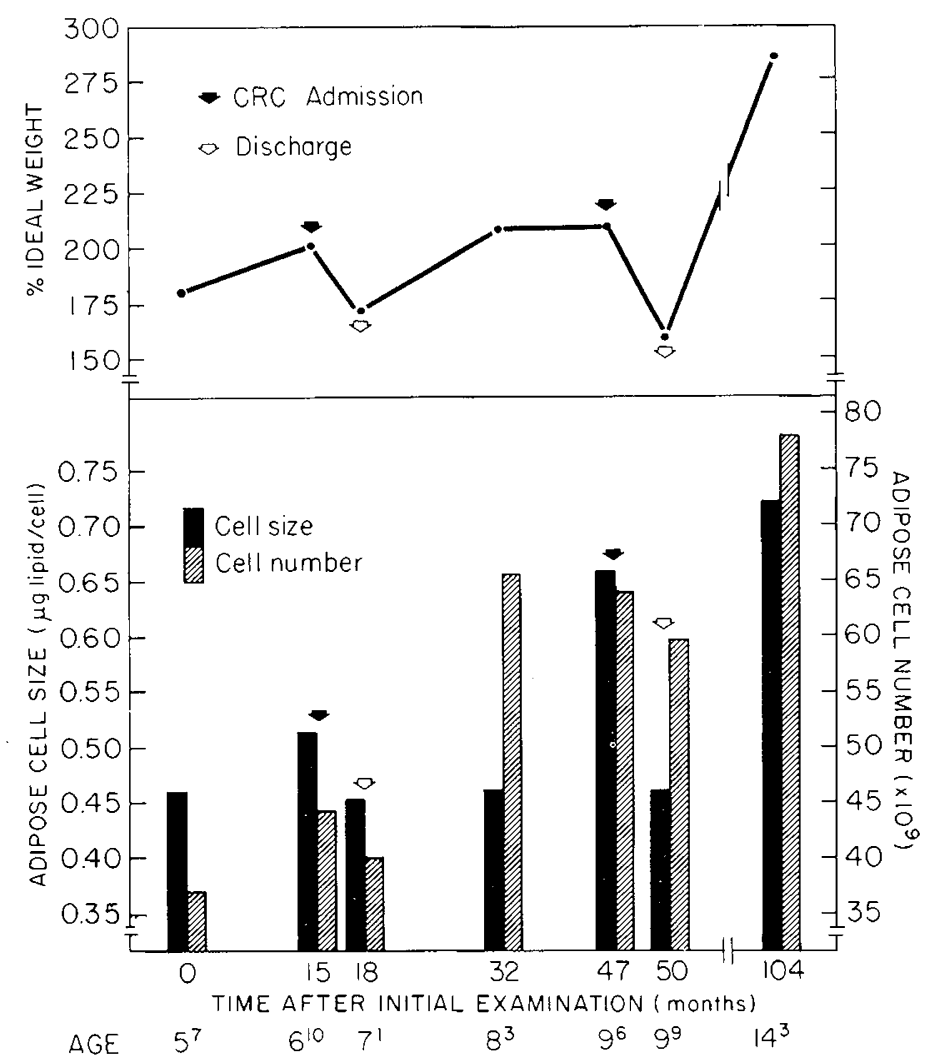

Fig. 2. Percent ideal body weight, adipose tissue cell size, and cell number over 104 months time span in patient $\mathrm{I}$. G. impractical, if not impossible, to frequently sample multiple sites for adipose tissue.

The concept of hypercellularity has been challenged on the basis that empty fat cells cannot be counted using the osmium tetroxide method of fixation (50). Although some "preadipocytes" may be missed using these methods, it has never been shown conclusively that such precursors exist in humans. If precursors do exist, our longitudinal data from obese and normal children provide no evidence that they are filled with fat at different rates. We conclude that groups increase their fat cell numbers during adolescence, but the distinct differences in fat cell number persist between normal and obese adolescents. Retrospective studies, which have not been able to demonstrate these relationships, (22) are obviously not as reliable as prospective longitudinal ones.

These longitudinal data strongly indicate that it is very difficult to reduce and maintain weight reduction in very young grossly obese youngsters. Furthermore, the results of this study question the efficacy of various short-term weight reduction programs and suggest that these programs be reassessed. Our data support the early work of Lloyd et al. (33) who demonstrated that $80 \%$ of obese children who underwent weight reduction relapsed 9 years later. Ours is the first long-term study of obese children undergoing early intervention which includes in vitro metabolic and cellular studies of adipocytes. It seems logical that the earlier dietary intervention occurs, the more likely it would be to decelerate the development of new fat cells and achieve positive long-term results. For example, no statistical increase in cell number was noted in patient $M$. C. over a 3 year period (from age two years, five months to age five years, 4 months). It is during this same time that other obese children of identical age increased their cell numbers (32). Previous studies on adipose cell number in nonobese

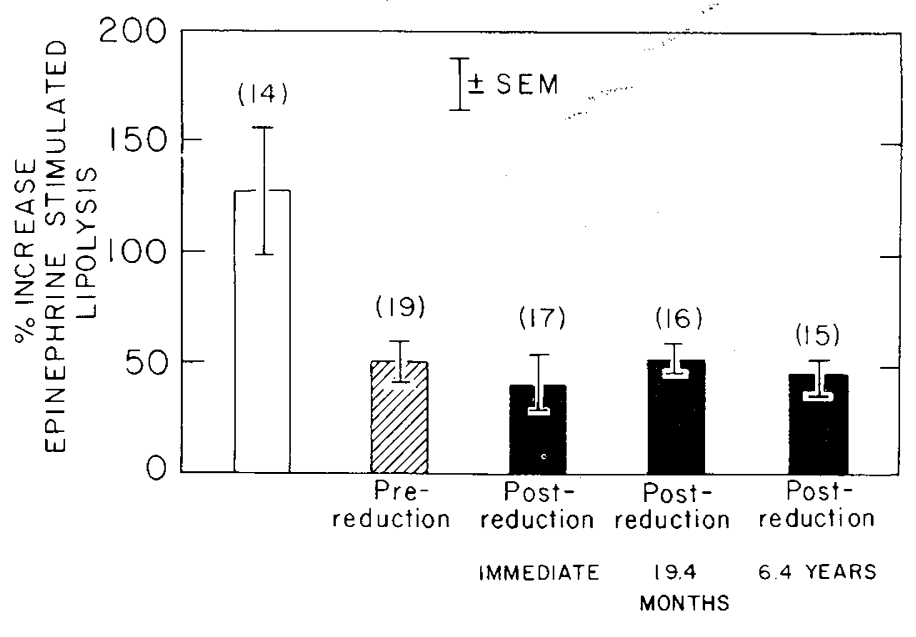

NORMAL

\section{OBESE}

Fig. 3. In vitro percent increase over baseline of epinephrine-stimulated lipolysis in adipocytes of control and obese children preweight reduction and at various time intervals postweight reduction.

Table 4. Correlation analysis of adipose cell size and cell number with other parameters pre- and postweight reduction

\begin{tabular}{|c|c|c|c|c|c|c|c|c|}
\hline & \multicolumn{4}{|c|}{ Period I } & \multicolumn{4}{|c|}{ Period II } \\
\hline & \multicolumn{2}{|c|}{ Adipose cell size } & \multicolumn{2}{|c|}{ Adipose cell no. } & \multicolumn{2}{|c|}{ Adipose cell size } & \multicolumn{2}{|c|}{ Adipose cell no. } \\
\hline & $\begin{array}{l}\text { Correlation } \\
\text { coefficient }\end{array}$ & $P$ & $\begin{array}{l}\text { Correlation } \\
\text { coefficient }\end{array}$ & $P$ & $\begin{array}{l}\text { Correlation } \\
\text { coefficient }\end{array}$ & $P$ & $\begin{array}{l}\text { Correlation } \\
\text { coefficient }\end{array}$ & $P$ \\
\hline Age & 0.49 & 0.006 & 0.62 & 0.0003 & 0.50 & 0.005 & 0.62 & 0.0003 \\
\hline Total body wt. & 0.39 & 0.03 & 0.84 & 0.0001 & 0.42 & 0.02 & 0.81 & 0.0001 \\
\hline$\%$ ideal body wt. & -0.008 & 0.96 & 0.38 & 0.04 & -0.10 & 0.60 & 0.27 & 0.15 \\
\hline
\end{tabular}



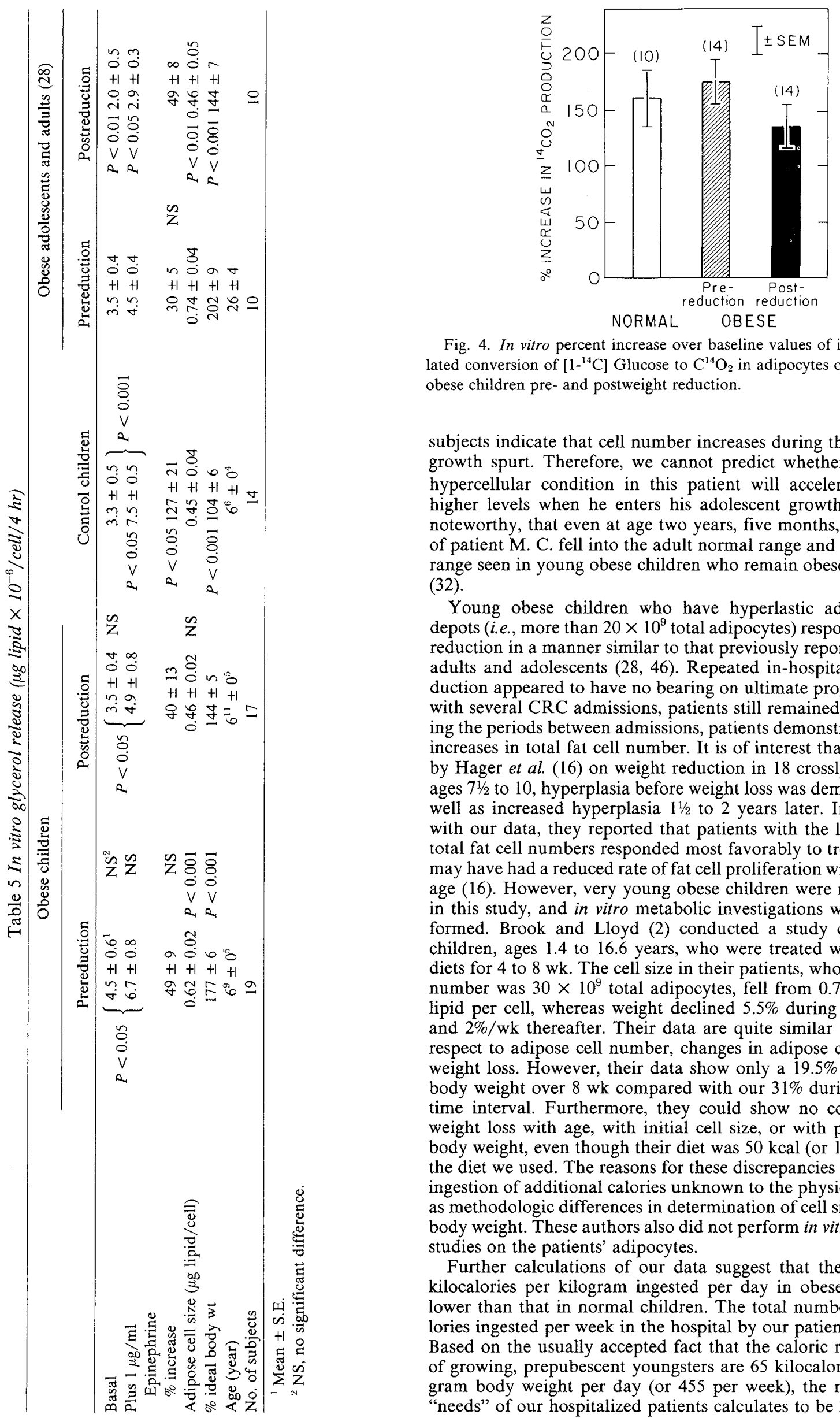

Fig. 4. In vitro percent increase over baseline values of insulin-stimulated conversion of $\left[1{ }^{14} \mathrm{C}\right]$ Glucose to $\mathrm{C}^{14} \mathrm{O}_{2}$ in adipocytes of control and obese children pre- and postweight reduction.

subjects indicate that cell number increases during the pubescent growth spurt. Therefore, we cannot predict whether or not the hypercellular condition in this patient will accelerate to even higher levels when he enters his adolescent growth spurt. It is noteworthy, that even at age two years, five months, the cell size of patient M. C. fell into the adult normal range and also into the range seen in young obese children who remain obese later in life (32).

Young obese children who have hyperlastic adipose tissue depots (i.e., more than $20 \times 10^{9}$ total adipocytes) respond to weight reduction in a manner similar to that previously reported in obese adults and adolescents $(28,46)$. Repeated in-hospital weight reduction appeared to have no bearing on ultimate prognosis. Even with several CRC admissions, patients still remained obese. During the periods between admissions, patients demonstrated further increases in total fat cell number. It is of interest that in a report by Hager $e$ et al. (16) on weight reduction in 18 crossly obese girls ages $7 \frac{1}{2}$ to 10 , hyperplasia before weight loss was demonstrated as well as increased hyperplasia $I^{1 / 2}$ to 2 years later. In agreement with our data, they reported that patients with the lowest initial total fat cell numbers responded most favorably to treatment and may have had a reduced rate of fat cell proliferation with increased age (16). However, very young obese children were not included in this study, and in vitro metabolic investigations were not performed. Brook and Lloyd (2) conducted a study on 26 obese children, ages 1.4 to 16.6 years, who were treated with $350 \mathrm{kcal}$ diets for 4 to $8 \mathrm{wk}$. The cell size in their patients, whose mean cell number was $30 \times 10^{9}$ total adipocytes, fell from 0.72 to $0.41 \mu \mathrm{g}$ lipid per cell, whereas weight declined 5.5\% during the first wk and $2 \% /$ wk thereafter. Their data are quite similar to ours with respect to adipose cell number, changes in adipose cell size, and weight loss. However, their data show only a $19.5 \%$ loss of total body weight over 8 wk compared with our $31 \%$ during the same time interval. Furthermore, they could show no correlation of weight loss with age, with initial cell size, or with percent ideal body weight, even though their diet was $50 \mathrm{kcal}$ (or 12.5\%) below the diet we used. The reasons for these discrepancies may include ingestion of additional calories unknown to the physicians as well as methodologic differences in determination of cell size and ideal body weight. These authors also did not perform in vitro metabolic studies on the patients' adipocytes.

Further calculations of our data suggest that the number of kilocalories per kilogram ingested per day in obese children is lower than that in normal children. The total number of kilocalories ingested per week in the hospital by our patients was 2800 . Based on the usually accepted fact that the caloric requirements of growing, prepubescent youngsters are 65 kilocalories per kilogram body weight per day (or 455 per week), the mean caloric "needs" of our hospitalized patients calculates to be $22,386 \mathrm{kcal} /$ 
wk (42). If they ingested only 2800 kilocalories per wk, then they had a deficit of $19,586 \mathrm{kcal}$ which should result in a mean loss of $2.55 \mathrm{~kg} /$ wk compared to the observed $1.1 \mathrm{~kg}$. Even if we calculate the body's needs based on providing a caloric intake of $65 \mathrm{kcal} /$ $\mathrm{kg} /$ day to the patients' lean body mass plus $15 \%$ (the average value for percent body fat for normal children over the age of two) (36), we would have expected a weight loss of $1.8 \mathrm{~kg} / \mathrm{wk}$ as opposed to the $1.1 \mathrm{~kg}$ observed.

Similar decreased rates of weight reduction in nine fasting obese adults when compared with normal weight adults have recently been reported by Forbes and Drenick (10). Further support for reduced caloric needs (34) and energy use in the cells of obese persons has very recently been provided by DeLuise, et al. (6). They demonstrated the presence of reduced numbers of sodium pump units and reduced activity of the pump in erythrocytes of obese adults. Sodium- and potassium-dependent adenosine triphosphatase, the enzymatic expression of the sodium pump, uses 20 to $50 \%$ of total cellular thermogenesis. This results in decreased activity, which is not increased by weight reduction, and may account for the reduced metabolic rates in obesity. In addition, impaired thermogenetic responses to rises in circulating catecholamines have been demonstrated in vivo in human obese subjects (23). Our observation that in vitro epinephrine-stimulated lipolysis is depressed in obese children may be related to these reductions in sodium-potassium ATPase. Longitudinal studies of the sodium pump activity in both red cells and other tissues of obese children must now be performed to validate these hypotheses.

Therefore, it is important to note that all of the obese children in this study, similar to the adolescents previously reported (28), displayed a distinct blunting of in vitro adipocyte epinephrinestimulated lipolysis. Although preweight reduction, basal- and epinephrine-stimulated glycerol release values were higher in our younger obese patients than in the obese adolescents, they did not decrease to the low values seen in the older subjects postweight reduction. Postreduction, obese children still displayed a $75 \%$ increase in basal lipolysis over values obtained from data on reduced obese adolescents and adults at identical cell sizes $(0.46$ $\mu \mathrm{g}$ lipid per cell). Whereas the basal rate, prereduction, for the obese children was $49 \%$ greater, the mean cell size was $19 \%$ smaller. Similarly, absolute levels of epinephrine-stimulated lipolysis in the obese children as compared with the mature obese subjects were $29 \%$ higher preweight reduction and $69 \%$ postweight reduction. It can be speculated that age (and perhaps years of obesity) may be important factors in the metabolic responses of adipocytes. That age may be important is suggested by the work of Nyberg et al. (35) who reported increased rates of both basal lipolysis and absolute epinephrine-stimulated lipolysis in normal children 1 to 15 years. Our own unpublished data also reveal that both basal and epinephrine-stimulated glycerol release decrease in children as their age increases. Control children with a mean age of $6 \frac{1}{2}$ years have a basal glycerol release $50 \%$ above that of children whose mean age is 11 years. Reported increases in the percent epinephrine-stimulated lipolysis in children and adults also concur with our data (35). That percent increase in epinephrine-stimulated lipolysis does not change after weight reduction in obese adults was also documented by Ostman et al. (40).

Inasmuch as this defect in epinephrine-stimulated lipolysis does not disappear with weight reduction, even in the youngest patients, it is suggested that cyclic AMP formation via the enzyme adenyl cyclase (49) may be altered. Defects in this mechanism may be important factors in the development of the obese state. Defective lipolysis might then contribute to establishing and enlarging the adipose tissue depot by signaling for a greater production of adipocytes as a compensatory mechanism. Alternatively, growth hormone and/or insulin or somatomedin C (43) may play a role in the production of added number of fat cells. Growth hormone initially increases the number of fat cells in growth hormonedeficient children treated with exogenous hormone (31). However, all studies to date, conducted only on older children, have indicated low growth hormone levels in obese subjects (41). Unpub- lished studies from our laboratory indicate that growth hormone responses to insulin-induced hypoglycemia may be increased in very young obese subjects. Insulin, as a growth hormone, has long been discussed, but its role still remains to be proven $(3,47)$. In this connection, it is noteworthy that the obese youngsters in this study have plasma hyperinsulinemia in response to glucose stimulation. Therefore, several factors may be important in the pathogenesis of the documented hypercellularity. Of additional note is that our previously reported data (31) as well as that of Hager et al.(15) suggest that there may be an important coupling between fat cell size and adipocyte multiplication in man. We have previously shown (32) that when percent body fat exceeded 25\% (as in all obese patients reported here), cell number rose dramatically. Furthermore, percent fat strongly correlates with cell size in all our patients $(\mathrm{r}=0.58 ; P<0.05)$. This suggests a "triggering" of fat-cell proliferation at a set level of body fatness and/or cell lipid content (32). In addition, fat cell size in children destined to be of normal weight falls between ages one and two, whereas this decrease in the change of size fails to occur in those children who become obese (29).

Normal in vitro response of obese children's adipocytes to insulin (mean cell size, $0.62 \mu \mathrm{g}$ lipid cell prereduction) is comparatively greater than the responsivity previously reported in obese adults (46). This contrast may reflect the fact that obese adults have adipose cell sizes greater than $0.7 \mu \mathrm{g}$ of lipid per cell, and insulin responsivity at this size level decreases sharply. Although four of our patients also had cell sizes above $0.7 \mu \mathrm{g}$ of lipid per cell prereduction, only one (A. D., whose cell size was $0.99 \mu \mathrm{g}$ lipid per cell) displayed any significant decrement in fat cell responsivity to insulin. This reduction, 23\% below the mean for the other children, suggests that age is also an important factor in determining hormonal responsivity. Furthermore, insulin secretion, as well as action, can quantitatively change with increasing age. These data are compatible with the hypothesis that insulin insensitivity is secondary to obesity and not a primary factor in its development $(24,38,46)$.

Other factors are also determinants of adipocyte metabolism. The state of nutrition and adipose cell size have been shown to be important components in the patterns of basal- and insulin-stimulated glucose metabolism $(13,21)$. During high carbohydrate intake in adults, Salans et al. (44) demonstrated increased levels of basal glucose metabolism within adipocytes. Insulin sensitivity of such cells could also be altered such that in states of increased caloric intake, increased insulin sensitivity was induced in large fat cells whereas in states of decreased caloric intake, smaller adipose cells showed decreased insulin sensitivity. It is well to note that in the children studied, such differences were not demonstrated and insulin sensitivity was normal (although not as carefully studied as in patients of Salans et al.). Thus, such changes may also be related to the increasing age of patients studied. Whether dietary changes have any effect on epinephrine-stimulated lipolysis cannot be answered from this study. However, during high carbohydrate intakes (the usual diet of the patients described) or high fat intake (during the in hospital weight reduction period), no differences could be evoked. Therefore, it appears that reduction of epinephrine-stimulated lipolysis within adipocytes is a permanent feature of the hypercellular state in obese children. Furthermore, preliminary data in our laboratory have now documented such reductions in infants as young as 1 month of age, suggesting that genetic or in utero factors may be important. These influences are presently under intensive investigation.

It is not surprising that fat cells do not disappear in these children after weight reduction. Animal studies suggest that number can only be permanently decreased via in utero or preweaning reductions in diet. Projected, this time interval corresponds to the first 2 years of a child's life. It is well to note that none of the children reported here had nutritional intervention before their second birthday. Thus, total adipose tissue cell number appears to be the primary factor in estimating the ultimate risk for lifelong obesity. Early determination of this parameter in children deviat- 
ing significantly from expected percent ideal body weights for height and age is obviously of importance.

\section{REFERENCES AND NOTES}

1. Bray, G. A.: Measurement of subcutaneous fat cells from obese patients. Ann. Intern. Med., 73: 565 (1970).

2. Brook, G. G. D., and Lloyd J. K.: Adipose cell size and glucose tolerance in obese children and effects of diet. Arch. Dis. Child., 48: 301 (1973).

3. Cheek, D. B., and Graystone, J. E.: The action of insulin, growth hormone and epinephrine on cell growth in liver, muscle and brain of the hypophysectomized rat. Pediatr. Res., 3: 77 (1969).

4. Cohn, S. H., and Dombrowski, C. S.: Absolute measurement of whole-body potassium by gammaray spectrometry. J. Nucl. Med., 11: 239 (1970).

5. Cohn, S. H., Dombrowski, C. S., Pate, H. R., and Robertson, J. S.: A whole-body counter with an invariant response to radio-nuclide distribution and body size. Phys. Med. Biol., 14: 645 (1969).

6. Deluise, M., Blackburn, G. L., and Flier, J. S., Reduced activity of the red-cell sodium-potassium pump in human obesity. N. Engl. J. Med., 303: 1017 (1980).

7. Duckerts, M., and Bonnet, F.: Adipose cell size differences related to the site of adipose tissue biopsy in children. Biomedicine (Paris), 19: 214 (1973).

8. Flynn, M. A., Clark, J., Reid, J. C., and Chase G.: A longitudinal study of total body potassium in normal children. Pediatr. Res., 9: 834 (1975).

9. Flynn, M. A., Woodruff, C., Clark, J., and Chase, G.: Total body $\mathrm{K}$ in normal children. Pediatr. Res., 6: 239 (1972).

10. Forbes, G. B., and Drenick, E. J.: Loss of body nitrogen on fasting. Am. J. Clin. Nutr., 32: 1570 (1979).

11. Friis-Hansen, B.: Body water compartments in children: changes during growth and related changes in body composition. Pediatrics, 28: 169 (1961).

12. Ginsberg-Fellner, F., and Knittle, J. L.: Adipose tissue cellularity and metabolism in newly diagnosed juvenile diabetics. Diabetes, 22: 528 (1973)

13. Goldrick, R. B., and McLoughlin, G. M.: Lipolysis and lipogenesis from glucose in fat cells of different sizes: effects of insulin, epinephrine and theophylline. J. Clin. Invest., 49: 1213 (1970).

14. Growth charts. Department of Health, Education, and Welfare, Public Health Service, Health Resources Administration, National Center for Health Statistics and Center for Disease Control, 1976.

15. Hager, A. L., Sjostrom, L., Arvidsson, B., Bjorntorp, P., and Smith, U.: Body fat and adipose tissue cellularity in infants: a longitudinal study. Metabolism, 26 : 607 (1977).

16. Hager, A., Sjostrom, L., Arvidsson, B., Bjorntorp, P., and Smith, U.: Adipose tissue cellularity in obese school girls before and after dietary treatment. Am. J. Clin. Nutr., 31: 68 (1978).

17. Harrison, L. C., Martin, F. I. R., and Melick, R. A.: Insulin receptor binding in isolated fat cells and insulin sensitivity in obesity. J. Clin. Invest., 58: 1435 (1976)

18. Hirsch, J., and Gallian, E.: Methods for the determination of adipose cell size and cell number in man and animals. J. Lipid. Res., 9: 110 (1968).

19. Hirsch, J., and Goldrick, R. B.: Serial studies on the metabolism of human adipose tissue. I. Lipogenesis and free fatty acid uptake and release in small aspirated samples of subcutaneous fat. J. Clin. Invest., 43: 1776 (1964).

20. Hirsch, J., and Knittle, J. L.: Cellularity of obese and non-obese human adipose tissue. Fed Proc., 29: 1516 (1970)

21. Jacobson, B., Holm, G., Bjorntorp, P., and Smith, U.: Influence of cell size on the effects of insulin and noradrenalin on human adipose tissue. Diabetologia, 12: 69 (1976).

22. Jung, R. T., Gurr, M. I., Robinson, M. P., and James, W. P. T., Does adipocyte hypercellullarity in obesity exist? Br. Med. J., 2: 319 (1978).

23. Jung, R. T., Shetty, P. S., James, W. P. T., Barrand, M. A., and Callingham, B. A.: Reduced thermogenesis in obesity. Nature (Lond.), 279: 322 (1979).

24. Kalkhoff, R. K., Kim, H. J., Cerletty, J., and Ferrou, C. M.: Metabolic effects of weight loss in obese subjects. Changes in plasma substrate levels, insulin and growth hormone responses. Diabetes, 20: 83 (197ł).

25. Khan, M. A., Ashman, R. S., Heald, F. P., and Hubbard, T. B., Jr.: Effects of methodology on estimation of adipose cell size and number in humans. Nutr. Rep. Int., 10: 9 (1974).

26. Knittle, J. L.: Maternal diet as a factor in adipose tissue cellularity and metabolism in the young rat. J Nutr., 102: 427 (1972).

27. Knittle, J. L.: Obesity in childhood: a problem in adipose tissue cellular development. J. Pediatr 81: 1048 (1972).

28. Knittle, J. L., and Ginsberg-Fellner, F.: Effect of weight reduction on in vitro adipose tissue lipolysis and cellularity in obese adolescents and adults. Diabetes, 21: 754 (1972).
29. Knittle, J. L., Ginsberg-Fellner, F., and Brown, R. E.: Adipose tissue development in man. Am. J. Clin. Nutr., 30: 762 (1977).

30. Knittle, J. L., and Hirsch, J.: Effect of early nutrition on the development of rat epididymal fat pads: cellularity and metabolism. J. Clin. Invest, 47: 2091 (1968).

31. Knittle, J. L., Sussman, L., Ginsberg-Fellner, F., and Gertner, M.: Effect of hormonal activity on human adipose tissue cellularity. J. Clin. Invest., 51: $55 \mathrm{a}$ (1971).

32. Knittle, J. L., Timmers, K., Ginsberg-Fellner, F., Brown, R. E., and Katz, D. P The growth of adipose tissue in children and adolescents. Cross-sectional and longitudinal studies of adipose cell number and size. J. Clin. Invest., 63: 239 (1979).

33. Lloyd, J. K., Wolff, O. H., and Whelen, W. S.: Childhood obesity: a long-term study of height and weight. Br. Med. J., 2: 145 (1961).

34. Miller, D. S., and Parsonage, S.: Resistance to slimming: adaptation or illusion. Lancet., 1: 773 (1975).

35. Nyberg, G., Hager, A., and Smith, U.: Effect of age on human adipose tissue metabolism and hormonal responsiveness. Acta Paediatr. Scand., 66: 495 (1977).

36. Obesity in America. Ed GA Bray, NIH Publication, No. 79-359, p. 95 (1979)

37. Olefsky, J. M.: Decreased insulin binding to adipocytes and circulating monocytes from obese subjects. J. Clin. Invest., 57: 1165 (1976).

38. Olefsky, J. M., Reaven, G. M., and Farquahar, J. W.: Effects of weight reduction on obesity: studies of carbohydrate and lipid metabolism. J. Clin. Invest., 53: 64 (1974)

39. Oscai, C. B., Babirak, S. P., McGarr, J. A., and Spirakis, C. N.: Effect of excercise on adipose tissue cellularity. Fed. Proc., 33: 1956 (1974)

40. Ostman, J. Brackman, L., and Hallberg, D.: Cell size and lipolysis by human subcutaneous adipose tissue. Acta Med. Scand., 193: 469 (1973).

41. Parra, A., Schultz, R. B., Graystone, J. E., and Cheek, D. B.: Correlative studies in obese children and adolescents concerning body composition and plasma insulin and growth hormone levels. Pediatr. Res., 5: 605 (1971).

42. Pediatric Nutrition Handbook, American Academy of Pediatrics, Evanston IL p. 82 (1979).

43. Phillips, L. S., and Orawski, A. T.: Nutrition and somatomedin. III. Diabetic control, somatomedin and growth in rats. Diabetes, 26: 864 (1977).

44. Salans, L. B., Bray, G. A., Cushman, S. W., Danforth, E., Jr., Glennon, J. A. Horton, E. S., and Sims, E. A. H.: Glucose metabolism and the response to insulin by human adipose tissue in spontaneous and experimental obesity. Effects of dietary composition and adipose cell size. J. Clin. Invest., 53: 848 (1974).

45. Salans, L. B., Cushman, S. W., and Weismann, R. E.: Adipose cell size and number in non-obese and obese patients. J. Clin. Invest., 52: 929 (1973).

46. Salans, L. B., Knittle, J. L., and Hirsch, J.: The role of adipose cell size and adipose tissue insulin sensitivity in the carbohydrate intolerance of human obesity. J. Clin. Invest., 47: 153 (1968).

47. Salter, J., and Best, C. H.: Insulin as a growth hormone. Br. Med. J., 2: 353 (1953).

48. Stuart, H. C., and Meredith, H. V.: Use of body measurements in the school health program. Am J Public Health, 36: 1365 (1946).

49. Sutherland, E. W., and Robison, G. A.: The role of cyclic AMP in the control of carbohydrate metabolism. Diabetes, 18: 797 (1969).

50. Widdowson, E. M., and Shaw, W. R.: Full and empty fat cells. Lancet, 2: 905 (1973).

51. Wieland, O.: Assay of glycerol. In: U. Bergmeyer: Methods of Enzymatic Analysis. Ed. 1, p. 211 Academic Press, Inc., New York, (1963).

52. Presented in part at the 1973 meeting of the Society for Pediatric Research

53. The authors would like to thank Dr. Stanton Cohn and Michael Stravino of the Brookhaven National Laboratories, Upton, Long Island, NY, for performing the total body potassium measurements; Lily Kiang, John Farrelly, and Moses Credit for expert technical assistance; Marcia Kalin, Judith Gilbride, and Wahida Karmally for nutritional guidance of the patients, the entire nursing staff on the Clinical Research Center at Mount Siani Hospital for the expert care given to the 2 I children hospitalized there, and Dr. Harry Smith, Chairman of the Department of Biostatistics at the Mount Sinai School of Medicine for help with the statistical analyses.

54. Requests for reprints should be addressed to: Dr. Fredda Ginsberg-Fellner, Department of Pediatrics, Division of Pediatric Endocrinology and Metabolism, Mount Sinai School of Medicine, One Gustve L. Levy Place, New York, NY 10029 (USA)

55. This research was supported in part by NIH Grants HD 03326 and RR-71, Division of Research Resources, General Clinical Research Centers Branch.

56. Received for publication April 10, 1978.

57. Accepted for publication February $9,1981$. 